\title{
Variations in the Visual Probe Paradigms for Attention Bias Modification for Substance Use Disorders
}

\author{
Melvyn Zhang ${ }^{1,2, *}$, Daniel S. S. Fung ${ }^{3}$ and Helen Smith ${ }^{2}$ \\ 1 National Addiction Management Service, Institute of Mental Health, Singapore 539747, Singapore \\ 2 Family Medicine \& Primary Care, Lee Kong Chian School of Medicine, Nanyang Technological University \\ Singapore, Singapore 308232, Singapore; h.e.smith@ntu.edu.sg \\ 3 Institute of Mental Health, Department of Developmental Psychiatry, Singapore 539747, Singapore; \\ daniel_fung@imh.com.sg \\ * Correspondence: melvynzhangweibin@gmail.com; Tel.: +65-3892504
}

Received: 7 August 2019; Accepted: 9 September 2019; Published: 12 September 2019

\begin{abstract}
Advances in experimental psychology have provided evidence for the presence of attentional and approach biases in individuals with substance use disorders. Traditionally, reaction time tasks, such as the Stroop or the Visual Probe Task, are commonly used in the assessment of attention biases. The Visual Probe Task has been criticized for its poor reliability, and other research has highlighted that variations remain in the paradigms adopted. However, a gap remains in the published literature, as there have not been any prior studies that have reviewed stimulus timings for different substance use disorders. Such a review is pertinent, as the nature of the task might affect its effectiveness. The aim of this paper was in comparing the different methods used in the Visual Probe Task, by focusing on tasks that have been used for the most highly prevalent substance disorders-that of opiate use, cannabis use and stimulant use disorders. A total of eight published articles were identified for opioid use disorders, three for cannabis use disorders and four for stimulant use disorders. As evident from the synthesis, there is great variability in the paradigm adopted, with most articles including only information about the nature of the stimulus, the number of trials, the timings for the fixation cross and the timings for the stimulus set. Future research examining attentional biases among individuals with substance use disorders should take into consideration the paradigms that are commonly used and evaluate the optimal stimulus and stimulus-onset asynchrony timings.
\end{abstract}

Keywords: Visual Probe Task; attention bias; cognitive bias; psychiatry

\section{Overview of Attention Bias Assessment and Modification}

Advances in experimental psychology have provided evidence for the presence of attentional and approach biases in individuals with substance use disorders. Attentional biases result in individuals having a preferential allocation of their attentional processes to substance-related stimuli [1], while approach biases result in individuals having automatic action tendencies in reaching out for substance-related cues [2]. Various theories have provided explanations for the presence of these biases, including that of the incentive-sensitization theory, the classical conditioning theory and that of the dual-process theory [3]. The dual-process theory is most commonly used in the justification of the presence of attentional biases. It postulates that the repeated use of a substance would result in increased automatic processing and increased automatic tendencies to approach substance-specific cues, with the inhibition of normal cognitive control processes [3]. The discovery and the understanding of these unconscious, automatic biases are of importance clinically, as they help to account for the lapses and relapses among individuals with substance use disorders [4]. Recent neuroimaging studies have highlighted that attentional biases are associated with increased activation in several 
neuroanatomical regions, including that of the anterior cingulate cortex, dorsolateral prefrontal cortex, insula, nucleus accumbens and amygdala $[5,6]$.

Traditionally, reaction time tasks, such as the Stroop or the Visual Probe Task, are commonly used in the assessment of attention biases [1]. In the Stroop task, individuals are required to name the colours of both the neutral and the drug-related words. In the Visual Probe Task, participants are required to respond readily to a probe that would replace either the neutral or the drug image. Attentional biases are deemed to be present if individuals respond more readily to a probe or words that replace substance-related images, as compared to the neutral word or images [1]. Ataya et al. (2012) [7] previously reported that both these tasks (the Stroop and Visual Probe Task) are associated with poor internal reliability. Field et al. (2012) [8] have postulated that one of the factors that could account for the poor reliability of the Visual Probe Task pertains to the type of stimulus used. Thus, the authors proposed the use of a personalised stimulus and images that participants could readily identify with. In turn, this could then result in a more demonstrable change in biases [8]. In a review by Lopes et al. (2015) [9], they reported that the Visual Probe Task was effective-in $88 \%$ of the studies involving individuals with substance use disorders, there was successful retraining of attentional biases. Jones et al. (2018) [10], in their recent study, have explored methods to improve the internal reliability of the Visual Probe Task. The authors examined the nature of the stimulus included, adopting the previous suggestion of having a personalised stimulus and reported that the inclusion of a personalised stimulus did help to improve the internal consistency of the Visual Probe Task.

Nevertheless, the authors still report the Visual Probe Task to be unreliable and that reliabilities were acceptable if the stimulus cues were presented for short intervals. Jones et al. (2018) [10], in their review, highlighted that there is great variation in the timings of the stimulus intervals used in published studies involving addiction. However, a gap remains in the published literature, as there have not been any prior studies that have reviewed the stimulus timings for the different substance use disorders. Such a review is pertinent, as the nature of the task might affect its effectiveness. Given this, our aim was to compare the different task paradigms and methods for the Visual Probe Tasks used for the most highly prevalent substance disorders-that of opiate use, cannabis use and stimulant use disorders.

\section{Visual Probe Trask Paradigms in Published Studies}

Two recent reviews have synthesised the evidence for attentional biases among substance users. Maclean et al. (2018) [11] identified 21 studies that have previously examined attentional biases in opioid using individuals. Zhang et al. (2018) [4] identified 11 articles involving participants with opioid use disorder, 16 articles with participants with stimulant use disorders and nine articles involving participants with cannabis use disorders. In order to fulfil our aim, we will describe the Visual Probe Task paradigms (the methods of the Visual Probe Tasks) that have been used in each of the published studies.

Table 1 provides an overview of the characteristics of the Visual Probe Task that were utilized in previous studies involving individuals with opioid use disorders. From both Maclean et al. (2018)'s [11] and Zhang et al. (2018)'s [4] review, we managed to identify a total of eight articles that specified the use of the Visual Probe Task for attention bias assessment or modification. We were unable to access the full text of one of the journals as it was published in a Chinese Journal. In the identified articles, there was great variability in the number of stimulus included, ranging from 12 to 44 picture pairs. Some studies included as few as 64 trials [12,13], while others included as many as 512 trials [14]. Across the studies, there was great variation in the Visual Probe Task. Most of the studies presented the fixation cross for 500 ms, except Frankland et al. (2016) [15] and Zhao et al. (2017) [16], who presented the fixation cross for $1000 \mathrm{~ms}$. Several studies have presented the stimulus and neutral image set for both a short and long duration [12-15,17,18]. The short stimulus timing was commonly that of $200 \mathrm{ms,}$ and the long stimulus timing was that of $2000 \mathrm{~ms}$, though, in Frankland et al. (2016)'s [15] study, they presented the images for 500 and $1500 \mathrm{~ms}$ as well. 
Table 1. Characteristics of the Visual Probe Task used in previous studies involving individuals with opioid dependence $(n=8)$.

\begin{tabular}{|c|c|c|c|c|c|}
\hline Study & Participants & Intervention Details & Nature of Stimulus Included & Details of Assessment Task & Outcomes \\
\hline $\begin{array}{l}\text { Charles et al. } \\
\text { (2015) [14] }\end{array}$ & $\begin{array}{l}\text { In total, } 23 \text { opiate } \\
\text { users and } 21 \text { healthy } \\
\text { controls }\end{array}$ & $\begin{array}{l}\text { Dot Probe Task for attention } \\
\text { retraining in the lab. } \\
\text { Participants maintained on } \\
\text { Buprenorphine and } \\
\text { Methadone Maintenance } \\
\text { Therapy (MMT) }\end{array}$ & $\begin{array}{l}\text { In total, } 44 \text { picture pairs } \\
\text { In total, } 40 \text { pairs matched for visual complexity } \\
\text { and composition, contained opiate-related } \\
\text { items (spoons, needles, lighters, heroin-like } \\
\text { substance) } \\
\text { The other four pairs were neutral images only }\end{array}$ & $\begin{array}{l}\text { Fixation Cross Timing: } 500 \mathrm{~ms} \\
\text { Stimulus Pair Timing: Short ( } 200 \mathrm{~ms} \text { ) or Long }(500 \mathrm{~ms}) \\
\text { Probe: Arrow pointing upwards or downwards, } \\
\text { remained on screen until participant responded } \\
\text { Probe Timing: Not mentioned } \\
\text { Inter-trial interval: } 250-500 \mathrm{~ms} \\
\text { Stimulus Onset Asynchrony (SOA): Not mentioned } \\
\text { Response Timing: Not mentioned } \\
\text { Total number of critical trials: } 64 \text { (assessment), } 512 \\
\text { (Intervention) } \\
\text { Total number of neutral trials: } 16 \\
\text { Total number of practice trials: Not mentioned }\end{array}$ & $\begin{array}{l}\text { No baseline difference in attention } \\
\text { bias between patients and controls } \\
\text { No significant effect of Attention } \\
\text { Bias Modification (ABM) on } \\
\text { Attention Bias (AB) or substance } \\
\text { cravings }\end{array}$ \\
\hline $\begin{array}{l}\text { Constantinou et al. } \\
\text { (2010) [17] }\end{array}$ & $\begin{array}{l}\text { In total, } 16 \text { opiate } \\
\text { users in treatment, } 16 \\
\text { ex-users, and } 16 \\
\text { healthy controls }\end{array}$ & $\begin{array}{l}\text { Dot Probe Task for attention } \\
\text { retraining in the lab. } \\
\text { Participants maintained on } \\
\text { methadone maintenance } \\
\text { therapy }\end{array}$ & $\begin{array}{l}\text { In total, } 40 \text { picture pairs } \\
\text { Of which, } 20 \text { pairs matched for visual } \\
\text { complexity and composition, and contained } \\
\text { one opiate related picture and one non opiate } \\
\text { related picture } \\
\text { The other } 20 \text { pairs were neutral pairs }\end{array}$ & $\begin{array}{l}\text { Fixation Cross Timing: Not mentioned } \\
\text { Stimulus Pair Timing: Short }(200 \mathrm{~ms}) \text { or Long }(2000 \mathrm{~ms}) \\
\text { Probe: Probe appeared on the side of the screen where one } \\
\text { of the pictures have been previously } \\
\text { Probe Timing: Not mentioned } \\
\text { Inter-trial interval: Not mentioned } \\
\text { SOA: Not mentioned } \\
\text { Response Timing: Not mentioned } \\
\text { Total number of critical trials: } 160 \\
\text { Total number of neutral trials: Not mentioned } \\
\text { Total number of practice trials: Not mentioned }\end{array}$ & $\begin{array}{l}\text { Greater attentional biases towards } \\
\text { drug-related stimuli for current } \\
\text { users, as compared to ex-users. } \\
\text { Ex-users showed a bias away from } \\
\text { drug-related stimuli in the stress } \\
\text { condition and this correlated } \\
\text { positively with their length of } \\
\text { abstinence }\end{array}$ \\
\hline $\begin{array}{l}\text { Frankland et al. } \\
\text { (2016) [15] }\end{array}$ & $\begin{array}{l}\text { In total, } 19 \text { were } \\
\text { opioid dependent and } \\
20 \text { healthy controls }\end{array}$ & $\begin{array}{l}\text { Dot Probe Task for attention } \\
\text { retraining in the lab. } \\
\text { Participants maintained on } \\
\text { partial MMT }\end{array}$ & $\begin{array}{l}\text { In total, } 14 \text { drug-related images (images of } \\
\text { drug paraphernalia and an unidentified addict } \\
\text { appearing to cook up and inject heroin), } \\
\text { Another } 14 \text { pairs matched for control pictures } \\
\text { (items from a children's building game, } \\
\text { and a person building a model railway) }\end{array}$ & $\begin{array}{l}\text { Fixation Cross Timing: } 1000 \mathrm{~ms} \\
\text { Stimulus Pair Timing: } 200,500 \text { and } 1000 \mathrm{~ms} \\
\text { Probe: Probe replaced the images. Participants to press one } \\
\text { of the buttons as quickly as quickly as possible, without } \\
\text { making mistakes, to indicate whether the probe appeared } \\
\text { on the left- or right-hand side. } \\
\text { Probe Timing: Not mentioned } \\
\text { Inter-trial interval: Not mentioned } \\
\text { SOA: Not mentioned } \\
\text { Response Timing: Not mentioned } \\
\text { Total number of critical trials: } 164 \\
\text { Total number of neutral trials: } 84 \\
\text { Total number of practice trials: } 10\end{array}$ & $\begin{array}{l}\text { Opioid dependent group had } \\
\text { a significant attentional bias for } \\
\text { opioid related information } \\
\text { presented at } 200 \mathrm{~ms} \text { and } 500 \mathrm{~ms} . \\
\text { No attentional biases at } 1500 \mathrm{~ms} \text {. }\end{array}$ \\
\hline $\begin{array}{l}\text { Garland et al. } \\
\text { (2013) [13] }\end{array}$ & $\begin{array}{l}\text { In total, } 32 \text { were } \\
\text { opioid dependent and } \\
33 \text { non } \\
\text { opioid-dependent }\end{array}$ & $\begin{array}{l}\text { Dot Probe Task for attentional } \\
\text { retraining in the lab } \\
\text { Participants maintained on } \\
\text { partial buprenorphine and } \\
\text { MMT }\end{array}$ & $\begin{array}{l}\text { In total, } 12 \text { opioid images, including photos of } \\
\text { pill (Oxycontin, Vicodin), pill bottles, crushed } \\
\text { and powdered opioids for insufflation, } \\
\text { and a syringe next to a vial of injectable } \\
\text { morphine } \\
\text { Neutral images included } 12 \text { photos from the } \\
\text { International Affective Picture System, } \\
\text { depicting household items }\end{array}$ & $\begin{array}{l}\text { Fixation Cross Timing: } 500 \mathrm{~ms} \\
\text { Stimulus Pair Timing: } 200 \text { or } 2000 \mathrm{~ms} \\
\text { Probe: Target probe will replace the images after } 50 \mathrm{~ms} \\
\text { inter-stimulus interval } \\
\text { Probe Timing: } 100 \mathrm{~ms} \\
\text { Inter-trial interval: Not mentioned } \\
\text { SOA: } 50 \mathrm{~ms} \\
\text { Response Timing: Not mentioned } \\
\text { Total number of critical trials: } 64 \\
\text { Total number of neutral trials: } 12 \\
\text { Total number of practice trials: Not mentioned }\end{array}$ & $\begin{array}{l}\text { Opioid-dependent individuals had } \\
\text { significant attention bias towards } \\
\text { opioids cues presented for } 200 \mathrm{~ms} \\
\text { but not for cues presented for } \\
2000 \mathrm{~ms}\end{array}$ \\
\hline
\end{tabular}


Table 1. Cont.

\begin{tabular}{|c|c|c|c|c|c|}
\hline Study & Participants & Intervention Details & Nature of Stimulus Included & Details of Assessment Task & Outcomes \\
\hline $\begin{array}{l}\text { Garland and } \\
\text { Howard et al. } \\
\text { (2014) [12] }\end{array}$ & $\begin{array}{l}\text { In total, } 28 \text { with a high } \\
\text { risk for misuse and } \\
19 \text { with a low risk for } \\
\text { misuse }\end{array}$ & $\begin{array}{l}\text { Dot Probe Task for attentional } \\
\text { retraining in the lab }\end{array}$ & $\begin{array}{l}\text { In total, } 12 \text { opioid images, including photos of } \\
\text { pill (Oxycontin, Vicodin), pill bottles, crushed } \\
\text { and powdered opioids for insufflation } \\
\text { Neutral images included } 12 \text { photos from the } \\
\text { International Affective Picture System (IAPS), } \\
\text { depicting household items }\end{array}$ & $\begin{array}{l}\text { Fixation Cross Timing: } 500 \mathrm{~ms} \\
\text { Stimulus Pair Timing: } 200 \text { or } 2000 \mathrm{~ms} \\
\text { Probe: Target probe will replace the images after } 50 \mathrm{~ms} \\
\text { inter-stimulus interval } \\
\text { Probe Timing: } 100 \mathrm{~ms} \\
\text { Inter-trial interval: Not mentioned } \\
\text { SOA: } 50 \mathrm{~ms} \\
\text { Response Timing: Not mentioned } \\
\text { Total number of critical trials: } 64 \\
\text { Total number of neutral trials: } 12 \\
\text { Total number of practice trials: Not mentioned }\end{array}$ & $\begin{array}{l}\text { Biased initial attentional orienting } \\
\text { to prescription opioid cues }\end{array}$ \\
\hline $\begin{array}{l}\text { Garland et al. } \\
\text { (2015) [18] }\end{array}$ & $\begin{array}{l}\text { In total, } 72 \text { opioid } \\
\text { misusers and } 26 \\
\text { opioids non misusers }\end{array}$ & $\begin{array}{l}\text { Dot Probe Task for attentional } \\
\text { retraining in the lab }\end{array}$ & $\begin{array}{l}\text { Pair of photos containing one emotionally } \\
\text { salient image and one neutral image } \\
\text { Three blocks of cues (opioid-related, } \\
\text { pain-related, and pleasure-related cues) } \\
\text { Opioid-related cues included images of pills } \\
\text { and bottles } \\
\text { Pain-related cues included images of severe } \\
\text { injuries, painful medical procedures, } \\
\text { and human faces grimacing in pain } \\
\text { Natural reward cues included images of } \\
\text { romantic couples and food } \\
\text { In total, } 36 \text { neutral images selected from } \\
\text { International Affective Picture System (IAPS) }\end{array}$ & $\begin{array}{l}\text { Fixation Cross Timing: } 500 \mathrm{~ms} \\
\text { Stimulus Pair Timing: } 200 \mathrm{or} 2000 \mathrm{~ms} \\
\text { Half of the trials presented at } 200 \mathrm{~ms} \text {, half } 2000 \mathrm{~ms} \text {. } \\
\text { Probe: Target probe will replace the images after } 50 \mathrm{~ms} \\
\text { inter-stimulus interval } \\
\text { Probe Timing: } 100 \mathrm{~ms} \\
\text { Inter-trial interval: Not mentioned } \\
\text { SOA: } 50 \mathrm{~ms} \\
\text { Response Timing: Not mentioned } \\
\text { Total number of critical trials: } 64 \\
\text { Total number of neutral trials: } 12 \\
\text { Total number of practice trials: Not mentioned }\end{array}$ & $\begin{array}{l}\text { Opioid misusers exhibit attentional } \\
\text { deficits during reward processing }\end{array}$ \\
\hline $\begin{array}{l}\text { Lubman et al. } \\
\text { (2000) [19] }\end{array}$ & $\begin{array}{l}\text { In total, } 16 \\
\text { methadone-maintained } \\
\text { addicts and } 16 \\
\text { age-matched controls }\end{array}$ & Pictorial Probe Detection task & $\begin{array}{l}\text { Drug-related photographs (drug } \\
\text { paraphernalia, for example, needles, spoons } \\
\text { and heroin wraps) } \\
\text { Scenes of unidentified addict cooking up and } \\
\text { injecting heroin. } \\
\text { Control photographs included items from } \\
\text { children building a game and scenes showing } \\
\text { an unidentified person building a model } \\
\text { railway using various components from the set }\end{array}$ & $\begin{array}{l}\text { Fixation Cross Timing: } 1000 \mathrm{~ms} \\
\text { Stimulus Pair Timing: } 500 \mathrm{~ms} \\
\text { Probe: After each pair of images, a dot probe will appear in } \\
\text { the position of one of the pictures } \\
\text { Participants are to press as quickly as possible, one of the } \\
\text { two response buttons. } \\
\text { Probe Timing: Not mentioned } \\
\text { Inter-trial interval: Not mentioned } \\
\text { SOA: Not mentioned } \\
\text { Response Timing: Not mentioned } \\
\text { Total number of critical trials: } 160 \\
\text { Total number of neutral trials: Not mentioned } \\
\text { Total number of practice trials: } 12\end{array}$ & $\begin{array}{l}\text { Attentional biases in opiate addicts } \\
\text { to probe that replaced the drug } \\
\text { pictures, rather than neutral images }\end{array}$ \\
\hline $\begin{array}{l}\text { Wei et al. } \\
\text { (2016) [20] }\end{array}$ & $\begin{array}{l}\text { In total, } 22 \text { heroin } \\
\text { addicts and } 22 \text { healthy } \\
\text { controls }\end{array}$ & Visual Probe Task & $\begin{array}{l}\text { In total, } 10 \text { heroin images } \\
\text { The other } 10 \text { were natural scenery pictures }\end{array}$ & $\begin{array}{l}\text { Fixation Cross Timing: } 1000 \mathrm{~ms} \\
\text { Stimulus Pair Timing: } 500 \mathrm{~ms} \\
\text { Probe: Appear in the location where one of the images } \\
\text { disappear } \\
\text { Probe Timing: } 200 \mathrm{~ms} \\
\text { Inter-trial interval: } 1350 \mathrm{~ms} \\
\text { SOA: Not mentioned } \\
\text { Response Timing: Not mentioned } \\
\text { Total number of critical trials: } 80 \text { and } 240 \\
\text { Total number of neutral trials: Not mentioned } \\
\text { Total number of practice trials: } 20\end{array}$ & $\begin{array}{l}\text { Heroin addicts have more rapid } \\
\text { response when the dot located on } \\
\text { the heroin-related picture as } \\
\text { compared to the neutral picture }\end{array}$ \\
\hline
\end{tabular}


Table 1. Cont.

\begin{tabular}{|c|c|c|c|c|c|}
\hline Study & Participants & Intervention Details & Nature of Stimulus Included & Details of Assessment Task & Outcomes \\
\hline $\begin{array}{l}\text { Zhao et al. } \\
\text { (2017) [16] }\end{array}$ & $\begin{array}{l}\text { In total, } 30 \\
\text { methadone-maintained } \\
\text { outpatients and } \\
38 \text { healthy controls }\end{array}$ & Visual Probe Task & $\begin{array}{l}\text { Drug neutral picture pairs and neutral-neutral } \\
\text { picture pairs. } \\
\text { In total, } 20 \text { pictures of substance-related scenes } \\
\text { and } 20 \text { similar pictures matched with same } \\
\text { layout but lacking substance-related cues } \\
\text { Another } 20 \text { pairs of pictures matched with } \\
\text { similar neutral scenes of daily life }\end{array}$ & $\begin{array}{l}\text { Fixation Cross Timing: } 1000 \mathrm{~ms} \\
\text { Stimulus Pair Timing: } 2000 \mathrm{~ms} \\
\text { Probe: Probe then displayed in one of the positions of } \\
\text { the pictures } \\
\text { Probe remained until the participant responded by clicking } \\
\text { the left or right button of mouse } \\
\text { Probe Timing: Not mentioned } \\
\text { Inter-trial interval: } 200 \mathrm{~ms} \\
\text { SOA: Not mentioned } \\
\text { Response Timing: Not mentioned } \\
\text { Total number of critical trials: } 120 \\
\text { Total number of neutral trials: Not mentioned } \\
\text { Total number of practice trials: } 16\end{array}$ & $\begin{array}{l}\text { Heroin group reacted faster to } \\
\text { probes associated with } \\
\text { substance-related pictures than } \\
\text { neutral pictures } \\
\text { More initial fixations } \\
\text { Maintained longer initial fixation } \\
\text { durations towards } \\
\text { substance-related pictures }\end{array}$ \\
\hline
\end{tabular}


While all the studies explicitly stated that they were based on the Visual Probe Task, there were variations in the nature of the task. Some studies $[12,13,18]$ have included an interstimulus interval, before the presentation of the probe. Also, in some studies, the probe remained on the screen until the participant made a response $[14,16,17]$, while in other studies, the probe only appeared for $100 \mathrm{~ms}$, before disappearing $[12,13,18]$. Some studies also included an inter-trial interval, but there was variation in the timing of this interval (from 250 to $2000 \mathrm{~ms}$ ). Some of the studies $[15,16,19]$ have included practice trials. Figure 1 provides a graphical representation of the details of the Visual Probe Task that were reported in each of the identified studies for opioid use disorder.

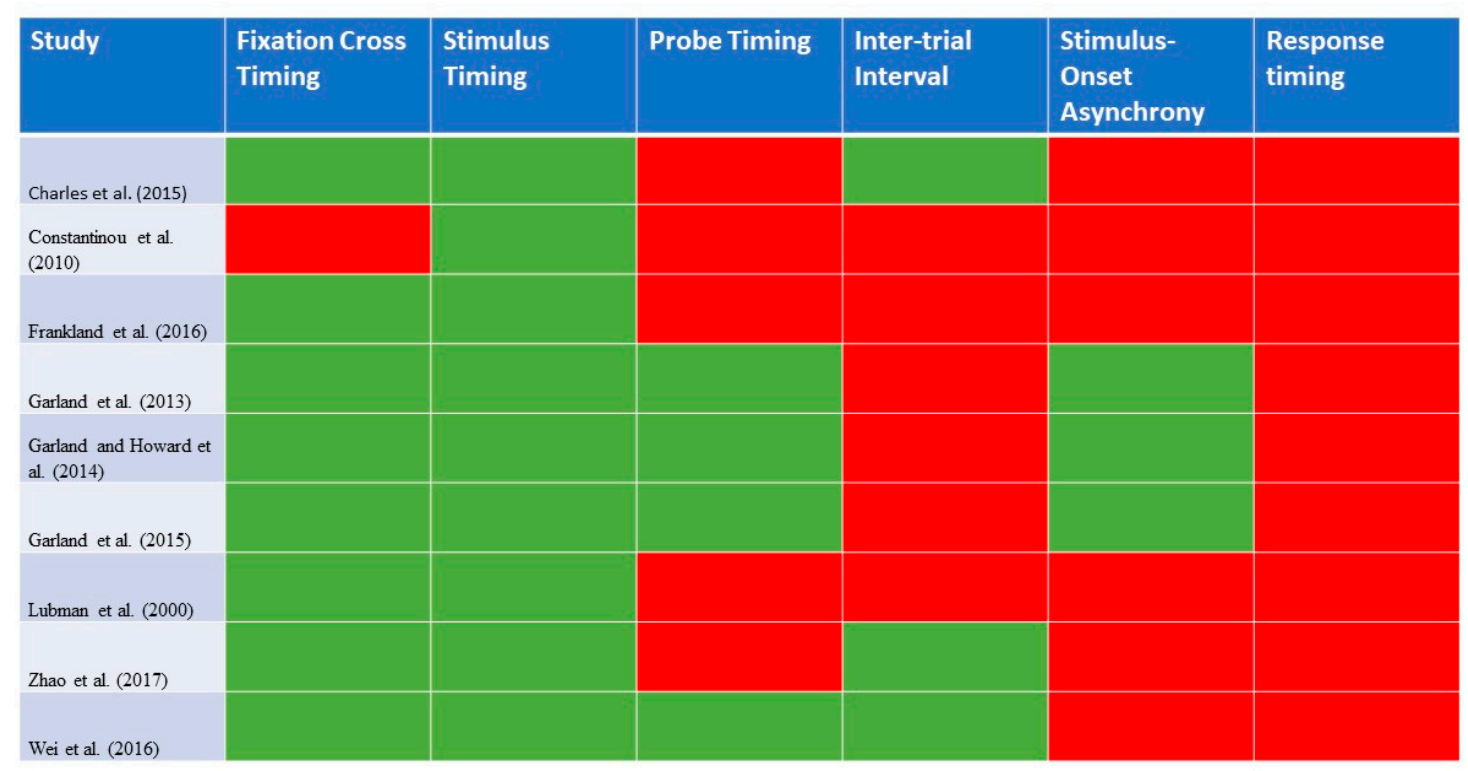

Figure 1. A graphical representation of the details of the Visual Probe Task that were reported in each of the identified studies for opioid use disorder $(n=8)$. Green highlights: reported in study; red highlights: not reported in study.

Table 2 provides an overview of the characteristics of the Visual Probe Task that was utilized in previous studies involving individuals with cannabis use disorders. A total of three articles from Zhang et al. (2018)'s [4] prior review were included, as they have reported the use of the Visual Probe Task. For the stimulus, Field et al. (2004) [21] included words instead of pictorial stimuli. In terms of the Visual Probe Task, two studies [21,22] presented the fixation cross for 500 ms, whereas Field et al. (2006) [23] presented it for $1000 \mathrm{~ms}$. There was again variation in the timings for the stimuli cues, with two studies [21,22] presenting the stimulus cue for $500 \mathrm{~ms}$, whereas that of Field et al. (2006) [23] presented it for $2000 \mathrm{~ms}$. In terms of probe presentation, two studies presented the probe [21,22] until a response was made. Vujanovic et al. (2016) [22], presented the probe for 125 or $250 \mathrm{~ms}$. Across all the studies, they have included an inter-trial interval, which ranged from 1000 to $1500 \mathrm{~ms}$. In terms of the number of trials, it ranged between 72 and 96. All the studies included practice trials for participants. Figure 2 provides a graphical representation of the details of the Visual Probe Task that were reported in each of the identified studies for cannabis use disorder. 
Table 2. Characteristics of the Visual Probe Task used in previous studies involving individuals with cannabis dependence.

\begin{tabular}{|c|c|c|c|c|c|}
\hline Study & Participants & Intervention Details & Nature of Stimulus Included & Details of Assessment Task & Outcomes \\
\hline $\begin{array}{l}\text { Field et al. } \\
\text { (2004) [21] }\end{array}$ & $\begin{array}{l}\text { In total, } 17 \text { regular } \\
\text { cannabis users and } 16 \\
\text { non-users }\end{array}$ & Visual Probe Task & $\begin{array}{l}\text { Cannabis-related words, } \\
\text { environment-related words, } \\
\text { pleasant words, } \\
\text { and unpleasant words }\end{array}$ & $\begin{array}{l}\text { Fixation Cross Timing: } 500 \mathrm{~ms} \\
\text { Stimulus Pair Timing: } 500 \mathrm{~ms} \\
\text { Probe: Immediately after the offset of the words, } \\
\text { a small dot probe was presented in the position of } \\
\text { one of the words, until the participant gave } \\
\text { a manual response. } \\
\text { Probe Timing: Not mentioned } \\
\text { Inter-trial interval: } 1000 \mathrm{~ms} \\
\text { Stimulus Onset Asynchrony (SOA): Not mentioned } \\
\text { Response Timing: Not mentioned } \\
\text { Total number of critical trials: } 64 \\
\text { Total number of neutral trials: } 32 \\
\text { Total number of practice trials: } 12\end{array}$ & $\begin{array}{l}\text { High levels of craving } \\
\text { associated with significant } \\
\text { attention bias for } \\
\text { cannabis-related words }\end{array}$ \\
\hline $\begin{array}{l}\text { Field et al. } \\
\text { (2006) [23] }\end{array}$ & $\begin{array}{l}\text { In total, } 23 \text { regular } \\
\text { cannabis users and } 23 \\
\text { non-user controls }\end{array}$ & $\begin{array}{l}\text { Visual Probe Task with } \\
\text { concurrent eye movement } \\
\text { monitoring }\end{array}$ & $\begin{array}{l}\text { In total, } 18 \text { cannabis-related } \\
\text { photographs } \\
\text { Depicting a scene relating to } \\
\text { cannabis use } \\
\text { Control photograph (did not } \\
\text { contain cannabis related content) }\end{array}$ & $\begin{array}{l}\text { Fixation Cross Timing: } 1000 \mathrm{~ms} \\
\text { Stimulus Pair Timing: } 2000 \mathrm{~ms} \\
\text { Probe: After picture offset, small visual probe (an } \\
\text { arrow which is pointed up or down) was presented } \\
\text { on the left or right of the screen } \\
\text { Respond to the probe as quickly as possible } \\
\text { Probe Timing: Not mentioned } \\
\text { Inter-trial interval: } 500 \mathrm{~ms} \\
\text { SOA: Not mentioned } \\
\text { Response Timing: Not mentioned } \\
\text { Total number of critical trials: } 72 \\
\text { Total number of neutral trials: Not mentioned } \\
\text { Total number of practice trials: } 10\end{array}$ & $\begin{array}{l}\text { Regular users had biases to } \\
\text { maintain gaze on cannabis cues } \\
\text { and faster approach responses } \\
\text { to cannabis cues }\end{array}$ \\
\hline $\begin{array}{l}\text { Vujanovic et al. } \\
\text { (2016) [22] }\end{array}$ & $\begin{array}{l}\text { In total, } 12 \text { adults with } \\
\text { cannabis use disorder and } \\
13 \text { controls }\end{array}$ & Visual Probe Task & $\begin{array}{l}\text { In total, six cannabis } \\
\text { pictures-cannabis-related stimuli- } \\
\text { and six neutral pictures matched in } \\
\text { size, colour and context }\end{array}$ & $\begin{array}{l}\text { Fixation Cross Timing: } 500 \mathrm{~ms} \\
\text { Stimulus Pair Timing: } 500 \mathrm{~ms} \\
\text { Probe: Probe stimulus removed, picture (cue) } \\
\text { remained on screen } 1500 \mathrm{~ms} \\
\text { Probe Timing: } 125 \text { or } 250 \mathrm{~ms} \\
\text { Inter-trial interval: } 1500 \mathrm{~ms} \\
\text { SOA: Not mentioned } \\
\text { Response Timing: } 1500 \mathrm{~ms} \\
\text { Total number of critical trials: } 96 \\
\text { Total number of neutral trials: Not mentioned } \\
\text { Total number of practice trials: } 12\end{array}$ & $\begin{array}{l}\text { Cannabis use group showed } \\
\text { greater attentional biases to } \\
\text { cannabis cues at the } 125 \mathrm{~ms} \\
\text { probe time }\end{array}$ \\
\hline
\end{tabular}




\begin{tabular}{|l|l|l|l|l|l|l|}
\hline Study & $\begin{array}{l}\text { Fixation Cross } \\
\text { Timing }\end{array}$ & $\begin{array}{l}\text { Stimulus } \\
\text { Timing }\end{array}$ & Probe Timing & $\begin{array}{l}\text { Inter-trial } \\
\text { Interval }\end{array}$ & $\begin{array}{l}\text { Stimulus- } \\
\text { Onset } \\
\text { Asynchrony }\end{array}$ & $\begin{array}{l}\text { Response } \\
\text { timing }\end{array}$ \\
\hline Field et al. (2004) & & & & & \\
\hline $\begin{array}{l}\text { Field et al. (2006) } \\
\text { Vujanovic et al. } \\
\text { (2016) }\end{array}$ & & & & & \\
\hline
\end{tabular}

Figure 2. A graphical representation of the details of the Visual Probe Task that were reported in each of the identified studies for cannabis use disorder $(n=3)$. Green highlights: reported in study; red highlights: not reported in study.

Table 3 provides an overview of the characteristics of the Visual Probe Task that were utilized in the previous studies involving individuals with stimulant use disorders-that of cocaine use disorders. A total of four articles from Zhang et al. (2018)'s [4] prior review was included. While all the studies have their basis in the Visual Probe Task, there was variability in the paradigms. Some studies included 10 sets of images [24], while others [25,26] included up to 20 sets of images. There was variation in the number of trials individuals had to undertake, ranging from 80 to 240 trials. Two studies [25,26] reported the inclusion of practice trials. Three out of the four studies reported that they presented a fixation cross for $500 \mathrm{~ms}$. In terms of stimulus timings, they were presented for $500 \mathrm{~ms}$ in three studies [24-26] and for a short (200 ms) and long (500 ms) interval in Mayer et al. (2016)'s study [27]. In all of the studies, the probe appeared up until a response was made. Only two of the four identified studies allowed for an inter-trial interval [24,27]. There was variation in the inter-trial interval, as it ranged from 500 to 1500 ms. Figure 3 provides a graphical representation of the details of the Visual Probe Task that were reported in each of the identified studies for stimulant use disorder. 
Table 3. Characteristics of the Visual Probe Task used in previous studies involving individuals with stimulant dependence.

\begin{tabular}{|c|c|c|c|c|c|}
\hline Study & Participants & Intervention Details & Nature of Stimulus Included & Details of Assessment Task & Outcomes \\
\hline Montgomery et al. (2010) [24] & $\begin{array}{l}\text { In total, } 32 \text { regular cocaine } \\
\text { users and } 40 \text { nonusers }\end{array}$ & $\begin{array}{l}\text { Visual Probe Task and } \\
\text { Modified Stroop Task }\end{array}$ & $\begin{array}{l}\text { In total, } 10 \text { pairs of images, } \\
\text { with one cocaine-related image } \\
\text { depicting cocaine, cocaine } \\
\text { paraphernalia, or close up of } \\
\text { an individual using cocaine } \\
\text { Matched with a neutral image, } \\
\text { perceptually similar to cocaine } \\
\text { image as possible, but did not have } \\
\text { cocaine content }\end{array}$ & $\begin{array}{l}\text { Fixation Cross Timing: } 500 \mathrm{~ms} \\
\text { Stimulus Pair Timing: } 500 \mathrm{~ms} \\
\text { Probe: Visual probe (an arrow pointing up or down) } \\
\text { presented in the location previously occupied by } \\
\text { one of the pictures } \\
\text { Required to rapidly identify the orientation of the } \\
\text { arrow probe by pressing the appropriate arrow on } \\
\text { the keyboard } \\
\text { Probe Timing: Not mentioned } \\
\text { Inter-trial interval: } 500 \mathrm{~ms} \\
\text { Stimulus Onset Asynchrony (SOA): Not mentioned } \\
\text { Response Timing: Not mentioned } \\
\text { Total number of critical trials: } 80 \\
\text { Total number of neutral trials: Not mentioned } \\
\text { Total number of practice trials: } 10\end{array}$ & $\begin{array}{l}\text { Cocaine participants who } \\
\text { consumed alcohol had } \\
\text { increased attentional biases } \\
\text { for cocaine pictures }\end{array}$ \\
\hline Tull et al. (2011) [26] & $\begin{array}{l}\text { In total, } 30 \text { cocaine- } \\
\text { dependent patients with } \\
\text { Post-traumatic Stress } \\
\text { Disorder (PTSD) and } 30 \\
\text { cocaine-dependent } \\
\text { patients without PTSD }\end{array}$ & Visual Probe Task & $\begin{array}{l}\text { In total, } 20 \text { cocaine-related images } \\
\text { (crack rocks, powder cocaine, crack } \\
\text { pipes, etc.) and } 40 \text { images } \\
\text { of furniture }\end{array}$ & $\begin{array}{l}\text { Fixation Cross Timing: } 500 \mathrm{~ms} \\
\text { Stimulus Pair Timing: } 500 \mathrm{~ms} \\
\text { Probe: Dot probe appeared in the left or right } \\
\text { position, remaining until the participant responded } \\
\text { Indicate where the dot appeared by pressing one of } \\
\text { the two response keys. } \\
\text { Probe Timing: Not mentioned } \\
\text { Inter-trial interval: } 250 \mathrm{~ms} \\
\text { SOA: Not mentioned } \\
\text { Response Timing: Not mentioned } \\
\text { Total number of critical trials: } 240 \\
\text { Total number of neutral trials: Not mentioned } \\
\text { Total number of practice trials: } 5\end{array}$ & $\begin{array}{l}\text { PTSD participants have had } \\
\text { greater attentional biases } \\
\text { towards the location of } \\
\text { cocaine imagery than } \\
\text { non-PTSD participants }\end{array}$ \\
\hline Bardeen et al. (2013) [25] & $\begin{array}{l}\text { In total, } 22 \text { cocaine- } \\
\text { dependent patients with } \\
\text { borderline personality } \\
\text { disorder and } 36 \text { cocaine- } \\
\text { dependent patients } \\
\text { without borderline } \\
\text { personality disorder }\end{array}$ & Visual Probe Task & $\begin{array}{l}\text { In total, } 20 \text { cocaine-related pictures } \\
\text { (crack pipes, crack rocks, etc.) and } \\
40 \text { pictures of furniture }\end{array}$ & $\begin{array}{l}\text { Fixation Cross Timing: } 500 \mathrm{~ms} \\
\text { Stimulus Pair Timing: } 500 \mathrm{~ms} \\
\text { Probe: Dot appeared on the screen replacing one of } \\
\text { the two pictures. } \\
\text { Press a button on the computer keyboard that } \\
\text { corresponded to the relative position of the dot on } \\
\text { the screen } \\
\text { Probe Timing: Not mentioned } \\
\text { Inter-trial interval: Not mentioned } \\
\text { SOA: Not mentioned } \\
\text { Response Timing: Not mentioned } \\
\text { Total number of critical trials: } 240 \\
\text { Total number of neutral trials: Not mentioned } \\
\text { Total number of practice trials: } 5\end{array}$ & $\begin{array}{l}\text { Greater bias for attending to } \\
\text { cocaine stimuli among male } \\
\text { cocaine-dependent patients } \\
\text { with or without borderline } \\
\text { personality disorder, when } \\
\text { presented with a trauma } \\
\text { script intervention }\end{array}$ \\
\hline
\end{tabular}


Table 3. Cont

\begin{tabular}{|c|c|c|c|c|c|}
\hline Study & Participants & Intervention Details & Nature of Stimulus Included & Details of Assessment Task & Outcomes \\
\hline Mayer et al. (2016) [27] & $\begin{array}{l}\text { In total, } 37 \text { participants } \\
\text { randomly assigned to } \\
\text { Attention Bias } \\
\text { Modification Therapt } \\
\text { (ABMT) or control } \\
\text { therapy }\end{array}$ & Visual Probe Task & $\begin{array}{l}\text { Cocaine and neutral stimuli were } \\
\text { equivalent in size and visual angle, } \\
\text { generally matched for colour } \\
\text { and content }\end{array}$ & $\begin{array}{l}\text { Fixation Cross Timing: Not mentioned } \\
\text { Stimulus Pair Timing: Stimulus pairs presented for } \\
200 \mathrm{~ms} \text { (speed detection trials) or } 500 \text { (difficulty to } \\
\text { disengage trials). } \\
\text { Probe: Stimulus replaced by a probe (arrow) } \\
\text { Probe Timing: Not mentioned } \\
\text { Inter-trial interval: } 1000 \text { or } 1500 \mathrm{~ms} \\
\text { SOA: Not mentioned } \\
\text { Response Timing: } 1500 \mathrm{~ms} \\
\text { Total number of critical trials: } 240 \\
\text { Total number of neutral trials: Not mentioned } \\
\text { Total number of practice trials: } 5\end{array}$ & $\begin{array}{l}\text { Attention bias modification } \\
\text { was not more effective than } \\
\text { control at reducing attentional } \\
\text { biases }\end{array}$ \\
\hline
\end{tabular}




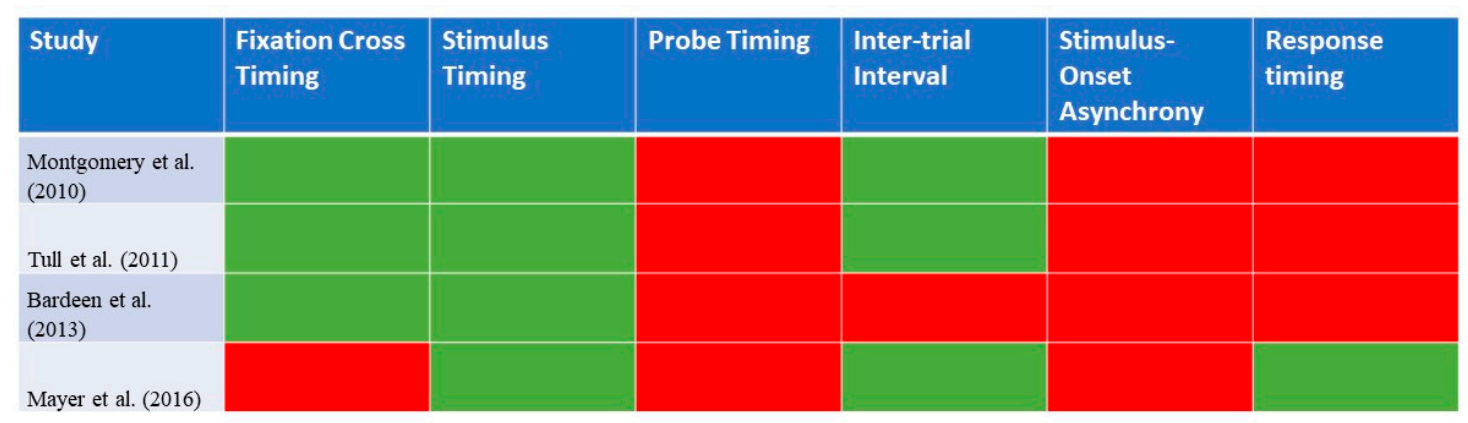

Figure 3. A graphical representation of the details of the Visual Probe Task that were reported in each of the identified studies for stimulant use disorder $(n=4)$. Green highlights: reported in study; red highlights: not reported in study.

\section{Implications for Future Research}

It is apparent that there is great variability in the paradigm of the Visual Probe Task. In addition, there is also a varied amount of information shared about the nature of the paradigm. Most of the articles included information about the nature of the stimulus, the number of trials, the timings for the fixation cross and the timings for the stimulus set. However, information is missing in some studies, with regards to the inter-stimulus interval, the time that the probe appears for, the inter-trial interview and the time allocated for the individual to response. The absence of this information limits the reproducibility of the Visual Probe Task by others. For future research, it is essential that the intervention is described in full, carefully specifying the full methodology of the Visual Probe Task used, in order to allow for the replication of studies.

While there were clear variations in the paradigms, there were some common elements across all the studies. For studies involving participants with opioid use disorders, most of the studies presented the fixation cross for $500 \mathrm{~ms}$ and presented the set of stimulus images for both a short and long stimulus duration. A shorter stimulus duration would allow for the evaluation of the initial, automatic detection attentional processes, while a longer stimulus duration would allow for the evaluation of the engagement stages of attention [9]. In contrast, for studies involving participants with cannabis use or stimulant use disorders, the stimulus pair was most commonly presented for $500 \mathrm{~ms}$. Most of the studies utilizing these timings have provided positive findings for attentional biases, except for Charles et al. (2015) [14] and Mayer et al. (2016) [27].

This evidence synthesis has direct implications for future research. We propose that future studies assessing and modifying attentional biases among individuals with opioid use disorders should consider the use of both a short and long stimulus timing, whereas studies evaluating attentional processes among people using cannabis or with stimulant disorders could use a single stimulus interval. To date, there is only a single study (Mayer et al., 2016) [27] that has examined a varying timing stimulus for individuals with stimulant use disorder. Future research should also examine whether the presence of a varying stimulus timing interval will enhance the detection and modification of attentional biases among individuals with cannabis and stimulant use disorders.

From the studies that we have included, there were a limited number of studies that have reported the stimulus-onset asynchrony timings. Lopes et al. (2015) [9], in their prior review exploring the Visual Probe Task for various disorders, have reported that there was variation in the timings for the different psychiatric disorders. For substance use disorders, it ranged from 50 to $500 \mathrm{~ms}$; for depressive disorders, it ranged from 500 to $2000 \mathrm{~ms}$; and for anxiety disorders, it ranged from 200 to $1500 \mathrm{~ms}$. Lopes et al. (2015) [9] have previously highlighted that a relatively longer stimulus duration is advantageous as it allows for participants to fully process the nature of the stimuli. However, as evident from this evidence synthesis, there are few studies that report on this timing, and this is indeed an area that future research should evaluate to determine the optimal interval for the different substance use disorders. 
Our article is perhaps the first article that has reviewed the task paradigms that have been adopted in previously published studies, involving individuals with substance use disorders. We managed to systematically extract information, primarily from the methods section of each manuscript, to ascertain the details of the visual probe paradigms that were utilized. However, there were limitations in our current study. We were unable to access the full text of one of the published articles, as it was published in a Chinese Journal. We have also attempted to contact each of the authors for further details about the Visual Probe Task they have previously used but, to date, we have only managed to receive replies from a single author, who stated that all the details have already been cited in the methods section of the published manuscript.

\section{Conclusions}

Our article has reviewed all the visual probe paradigms that have been applied previously for addiction and substance research. While there are variations in the underlying paradigms, there are some commonalities as well. Future research examining attentional biases among individuals with substance use disorders should take into consideration the paradigms that are commonly used and evaluate the optimal stimulus and stimulus-onset asynchrony timings.

Author Contributions: Conceptualization, M.Z., D.S.S.F., and H.S.; data collation, M.Z.; writing-original draft preparation, M.Z.; writing - review and editing, D.S.S.F. and H.S. All authors read and approved of the manuscript prior to submission.

Funding: M.Z. is supported by a grant under the Singapore Ministry of Health's National Medical Research Council (grant number NMRC/Fellowship/0048/2017) for PhD training. The funding source was not involved in any part of this project.

Conflicts of Interest: None of the authors have any competing interests.

\section{References}

1. Field, M.; Cox, W.M. Attentional bias in addictive behaviors: A review of its development, causes, and consequences. Drug Alcohol Depend. 2008, 97, 1-20. [CrossRef] [PubMed]

2. Eberl, C.; Wiers, R.W.; Pawelczack, S.; Rinck, M.; Becker, E.S.; Lindenmeyer, J. Approach bias modification in alcohol dependence: Do clinical effects replicate and for whom does it work best? Dev. Cogn. Neurosci. 2013, 4, 38-51. [CrossRef] [PubMed]

3. Stacy, A.W.; Wiers, R.W. Implicit cognition and addiction: A tool for explaining paradoxical behavior. Annu. Rev. Clin. Psychol. 2010, 6, 551-575. [CrossRef] [PubMed]

4. Melvyn, Z.W.; Ying, J.; Wing, T.; Guo, S.; Fung, D.S.; Smith, H. Cognitive Biases in Cannabis, Opioid, and Stimulant Disorders: A Systematic Review. Front. Psychiatry 2018, 9, 376.

5. Vollstädt-Klein, S.; Loeber, S.; Richter, A.; Kirsch, M.; Bach, P.; von der Goltz, C.; Hermann, D.; Mann, K.; Kiefer, F. Validating incentive salience with functional magnetic resonance imaging: Association between mesolimbic cue reactivity and attentional bias in alcohol-dependent patients. Addict. Biol. 2012, 17, 807-816. [CrossRef]

6. Hester, R.; Garavan, H. Neural mechanisms underlying drug-related cue distraction in active cocaine users. Pharmacol. Biochem. Behav. 2009, 93, 270-277. [CrossRef] [PubMed]

7. Ataya, A.F.; Adams, S.; Mullings, E.; Cooper, R.M.; Attwood, A.S.; Munafo, M.R. Internal reliability of measures of substance-related cognitive bias. Drug Alcohol Depend. 2012, 121, 148-151. [CrossRef]

8. Field, M.; Christiansen, P. Commentary on, 'Internal reliability of measures of substance-related cognitive bias'. Drug Alcohol Depend. 2012, 124, 189-190. [CrossRef]

9. Lopes, F.M.; Viacava, K.R.; Bizarro, L. Attentional bias modification based on visual probe task: Methodological issues, results and clinical relevance. Trends Psychiatry Psychother. 2015, 37, 183-193. [CrossRef]

10. Jones, A.; Christiansen, P.; Field, M. Failed attempts to improve the reliability of the alcohol visual probe task following empirical recommendations. Psychol. Addict. Behav. 2018, 32, 922-932. [CrossRef]

11. MacLean, R.R.; Sofuoglu, M.; Brede, E.; Robinson, C.; Waters, A.J. Attentional bias in opioid users: A systematic review and meta-analysis. Drug Alcohol Depend. 2018, 191, 270-278. [CrossRef] [PubMed] 
12. Garland, E.L.; Howard, M.O. Opioid attentional bias and cue-elicited craving predict future risk of prescription opioid misuse among chronic pain patients. Drug Alcohol Depend. 2014, 144, 283-287. [CrossRef] [PubMed]

13. Garland, E.L.; Froeliger, B.E.; Passik, S.D.; Howard, M.O. Attentional bias for prescription opioid cues among opioid dependent chronic pain patients. J. Behav. Med. 2013, 36, 611-620. [CrossRef] [PubMed]

14. Charles, M.; Wellington, C.E.; Mokrysz, C.; Freeman, T.P.; O'Ryan, D.; Curran, H.V. Attentional bias and treatment adherence in substitute-prescribed opiate users. Addict. Behav. 2015, 46, 100-105. [CrossRef] [PubMed]

15. Frankland, L.; Bradley, B.P.; Mogg, K. Time course of attentional bias to drug cues in opioid dependence. Psychol. Addict. Behav. 2016, 30, 601-606. [CrossRef]

16. Zhao, H.; Yang, B.; Zhu, Q.; Zhang, G.; Xiao, Y.; Guo, X.; Huang, X.; Zhang, Z. Eye Movement Evidence of Attentional Bias for Substance-Related Cues in Heroin Dependents on Methadone Maintenance Therapy. Subst. Use Misuse 2017, 52, 527-534. [CrossRef]

17. Constantinou, N.; Morgan, C.J.; Battistella, S.; O’Ryan, D.; Davis, P.; Curran, H.V. Attentional bias, inhibitory control and acute stress in current and former opiate addicts. Drug Alcohol Depend. 2010, 109, 220-225. [CrossRef]

18. Garland, E.L.; Froeliger, B.; Howard, M.O. Allostatic dysregulation of natural reward processing in prescription opioid misuse: Autonomic and attentional evidence. Biol. Psychol. 2015, 105, 124-129. [CrossRef]

19. Lubman, D.I.; Peters, L.A.; Mogg, K.; Bradley, B.P.; Deakin, J.F.W. Attentional bias for drug cues in opiate dependence. Psychol. Med. 2000, 30, 169-175. [CrossRef]

20. Tull, M.T.; McDermott, M.J.; Gratz, K.L.; Coffey, S.F.; Lejuez, C.W. Cocaine-related attentional bias following trauma cue exposure among cocaine dependent in-patients with and without post-traumatic stress disorder. Addiction 2011, 106, 1810-1818. [CrossRef]

21. Field, M.; Mogg, K.; Bradley, B.P. Cognitive bias and drug craving in recreational cannabis users. Drug Alcohol Depend. 2004, 74, 105-111. [CrossRef]

22. Vujanovic, A.A.; Wardle, M.C.; Liu, S.; Dias, N.R.; Lane, S.D. Attentional bias in adults with cannabis use disorders. J. Addict. Dis. 2016, 35, 144-153. [CrossRef]

23. Field, M. Cannabis 'dependence' and attentional bias for cannabis-related words. Behav. Pharmacol. 2005, 16, 473-476. [CrossRef]

24. Montgomery, C.; Field, M.; Atkinson, A.M.; Cole, J.C.; Goudie, A.J.; Sumnall, H.R. Effects of alcohol preload on attentional bias towards cocaine-related cues. Psychopharmacology 2010, 210, 365-375. [CrossRef]

25. Bardeen, J.R.; Dixon-Gordon, L.K.; Tull, M.T.; Lyons, J.A.; Gratz, K.L. An investigation of the relationship between borderline personality disorder and cocaine-related attentional bias following trauma cue exposure: The moderating role of gender. Compr. Psychiatry 2014, 55, 113-122. [CrossRef]

26. Mayer, A.R.; Wilcox, C.E.; Dodd, A.B.; Klimaj, S.D.; Dekonenko, C.J.; Claus, E.D.; Bogenschutz, M. The efficacy of attention bias modification therapy in cocaine use disorders. Am. J. Drug Alcohol Abuse 2016, 42, 459-468. [CrossRef]

27. Wei, Z.; Cai, H.; Zhao, Q.; Han, Q.; Ma, E.; Zhao, G.; Peng, H. An ERP Study of Attentional Bias to Drug Cues in Heroin Dependence by Using Dot-Probe Task. In Proceedings of the International Conference on Human Centered Computing, Colombo, Sri Lanka, 7-9 January 2016; Springer: Cham, Switzerland; pp. 794-799.

(C) 2019 by the authors. Licensee MDPI, Basel, Switzerland. This article is an open access article distributed under the terms and conditions of the Creative Commons Attribution (CC BY) license (http://creativecommons.org/licenses/by/4.0/). 